\title{
Incidence of Surgical Emergencies - A Hospital Based Study in Ranga Reddy District of Telangana
}

\author{
Yugandhar GR ${ }^{1}$, Losari Surender ${ }^{1}$, PV Chalam², Bhanu Prakash ${ }^{3}$, Raj shekhar ${ }^{3}$, Kovida $^{3}$ \\ ${ }^{1}$ Assistant Professor, Department Of Surgery, Bhaskar Medical College, Yenkapally, Moinabad, Telangana, ${ }^{2}$ Professor, Department Of Surgery, Bhaskar \\ Medical College, ${ }^{3} \mathrm{PG}$ in General Surgery, Bhaskar Medical College.
}

\section{Abstract}

Background: Surgical emergencies are unique group of cases which require quick decisions and these decisions have significant effect on outcome. Most of these surgeries performed in emergency situations where the value of the exhaustive investigations has to be balanced against any deterioration which may occur in patient's general condition due to inevitable delay. Objective: The objective of this study was to identify the spectrum of surgical emergencies and their outcome. Design: This was a hospital based prospective analysis of surgical emergencies presented to Unit I and V of General Surgery Department, Bhaskar General Hospital. Duration: Surgical emergencies over a period of three years from 2015 to 2017 were analyzed to identify the spectrum of surgical emergencies and their outcome. Setting: Department of General Surgery, Bhaskar Medical College, Yenkapally, Moinabad, Ranga Reddy District, Telangana, India. Participants: A total of 2372 patients who underwent emergency surgery in Unit I and Unit V of General Surgery Department, Bhaskar General Hospital. Subjects and Methods: A retrospective analysis of the reports of all the patients who were operated upon was performed to assess the spectrum of surgical emergencies and their outcome. Data was tabulated using MS Excel and statistical analysis was performed using appropriate statistical software. Results: Among Non-trauma cases, 51.24\% (472) were Appendicitis (i.e., 19.95\% of total cases), 34.90\% (322) were of Intestinal obstruction, $12.03 \%$ (114) were hollow viscus perforations and others include 0.71\% (56) of cases. Most of the surgeries were performed under spinal anaesthesia. A few cases were performed under General anaesthesia. Among trauma cases, $85.16 \%$ (1234) of them were minor injuries that required conservative management or minor surgeries \& $14.84 \%$ (215) of them were managed with major surgery. Conclusion: Among non-trauma cases, most of the cases were of intestinal obstruction and most of the surgeries were performed under spinal anaesthesia. Among trauma cases, most of them were minor injuries that required conservative management or minor surgeries and few of them were managed with major surgery.

Keywords: Surgical Emergencies, Incidence, Hospital Based Study, Outcome.

Corresponding Author: Dr. Losari Surender, MS(Gen. Surgery), Assistant Professor, Department Of Surgery, Bhaskar Medical College.

Received: June 2019

Accepted: July 2019

\section{Introduction}

Surgical emergencies are unique group of cases which require quick decisions and these decisions have significant effect on outcome. General Surgical Emergencies Commonly Seen in First and Second-Level Hospitals are Acute abdominal conditions, Incarcerated and Strangulated Inguinal Hernias, Appendicitis, Intestinal obstruction, Complications of peptic ulcer, including perforated ulcer and bleeding ulcer, Bleeding from esophageal varices, Pelvic infections with abscesses, Perforated typhoid ulcers, Amebic liver abscess, Gall bladder and bile duct disease, Respiratory obstruction, foreign bodies, and pleural disease, Urinary obstruction caused by stricture, stone, or prostatic enlargement, Surgical infections of the skin, muscles, bones, and joints. The World Health Organization's (WHO's) Global Health Estimates report surgical emergencies as high mortality medical conditions. The goals of management are to Recognize different surgical emergencies, Learn a correct notion, Decrease delayed diagnosis and to Prevent secondary injury. The principles of management include: Lifesaving Identify life-threatening injury and Appropriate resuscitation; Maintain vital status - Detailed physical examination and Continuous resuscitation; Further evaluation and management - Laboratory examination and Consultation. The objective of this study was to identify the spectrum of surgical emergencies and their outcome.

\section{Subjects and Methods}

Place Of Study: Department of General Surgery, Bhaskar Medical College, Yenkapally, Moinabad, Ranga Reddy District, Telangana, India.

Type Of Study: This was a hospital based prospective analysis of 2372 surgical emergencies presented to Unit I and Unit V of General Surgery Department, Bhaskar General Hospital.

Sample Collection: Sample Size: 2372 patients. Sampling Methods: Consecutive sampling. 
Statistical Methods: Statistical analysis was done using appropriate statistical software.

Ethical Approval: Approval was taken from the Institutional Ethics Committee prior to commencement of the study.

\section{Results}

A total of 2372 patients, $60.95 \%$ are males and $39.05 \%$ are females with the age group of $5-92$ years underwent emergency surgery. The surgeries included $61.07 \%$ (1449) of Trauma \& $38.93 \%$ (923) of Non-trauma cases.

As depicted in the following tables 1, 2 and 3; among Nontrauma cases, 51.24\% (472) were Appendicitis (i.e., 19.95\% of total cases), 34.90\% (322) were of Intestinal obstruction, $12.03 \%$ (114) were hollow viscus perforations and others include $0.71 \%$ (56) of cases. Most of the surgeries were performed under spinal anaesthesia. A few cases were performed under General anaesthesia.

Table 1: Appendicitis Cases

\begin{tabular}{|l|l|l|l|l|l|l|l|l|l|}
\hline Year & Patients & Male & Female & $<\mathbf{1 2}$ Yrs & $\mathbf{1 2 - 3 0 Y r s}$ & $\mathbf{> 3 0}$ Yrs & Sa & Ga & Appendicular Perforation \\
\hline 2015 & 148 & 82 & 66 & 28 & 99 & 21 & 102 & 46 & 46 \\
\hline 2016 & 121 & 68 & 53 & 31 & 65 & 25 & 88 & 33 & 33 \\
\hline 2017 & 203 & 112 & 91 & 50 & 121 & 32 & 146 & 57 & 57 \\
\hline
\end{tabular}

\section{Intestinal Obstruction}

Table 2: Intestinal Obstruction Cases

\begin{tabular}{|l|l|l|l|l|l|l|l|l|l|l|l|l|l|}
\hline Year & Patients & Male & Female & $<\mathbf{1 2 Y r s}$ & $\begin{array}{l}\mathbf{1 2 -} \\
\mathbf{3 0 Y r s}\end{array}$ & $\begin{array}{l}\mathbf{> 3 0} \\
\text { Yrs }\end{array}$ & Sa & Ga & Adhesions & $\begin{array}{l}\text { Obstructed } \\
\text { Hernias }\end{array}$ & $\begin{array}{l}\text { Sigmoid } \\
\text { Volvulus }\end{array}$ & Malignancies & Others \\
\hline 2015 & 102 & 64 & 38 & 02 & 06 & 94 & 25 & 77 & 55 & 28 & 09 & 06 \\
\hline 2016 & 97 & 55 & 42 & 0 & 02 & 95 & 16 & 81 & 47 & 21 & 12 & 04 \\
\hline 2017 & 123 & 70 & 53 & 04 & 07 & 116 & 31 & 92 & 68 & 35 & 08 & 07 \\
\hline
\end{tabular}

\section{Hollow Viscus Perforation}

Table 3: Hollow Viscus Perforation Cases.

\begin{tabular}{|l|l|l|l|l|l|l|l|l|l|l|l|}
\hline Year & Patients & Male & Female & $\mathbf{< 1 2 Y r s}$ & $\mathbf{1 2 - 3 0}$ Yrs & $\mathbf{> 3 0}$ Yrs & Sa & Ga & $\begin{array}{l}\text { Du } \\
\text { Perforation }\end{array}$ & $\begin{array}{l}\text { Gastric } \\
\text { Perforation }\end{array}$ & Ileal Perforation \\
\hline 2015 & 41 & 36 & 05 & 0 & 0 & 41 & 0 & 41 & 25 & 07 & 09 \\
\hline 2016 & 46 & 35 & 11 & 0 & 2 & 44 & 0 & 46 & 30 & 08 & 08 \\
\hline 2017 & 27 & 25 & 02 & 0 & 1 & 26 & 0 & 27 & 15 & 05 & 07 \\
\hline
\end{tabular}

As depicted in the following table no. 4, among trauma cases, $85.16 \%$ (1234) of them were minor injuries that required conservative management or minor surgeries \& $14.84 \%$ (215) of them were managed with major surgery.

\section{$\underline{\text { Trauma }}$}

\begin{tabular}{|c|c|c|c|c|c|c|c|c|c|c|c|c|c|c|c|c|c|}
\hline $\begin{array}{l}\text { Ye } \\
\text { ar }\end{array}$ & $\begin{array}{l}\text { Patie } \\
\text { nts }\end{array}$ & $\begin{array}{l}\text { Ma } \\
\text { le }\end{array}$ & $\begin{array}{l}\text { Fem } \\
\text { ale }\end{array}$ & $\begin{array}{l}<1 \\
2 \\
Y \\
\text { rs }\end{array}$ & $\begin{array}{l}12 \\
30 \\
\text { Y } \\
\text { rs }\end{array}$ & $\begin{array}{l}>3 \\
0 \\
Y \\
\text { rs }\end{array}$ & $\begin{array}{l}\text { Abrasi } \\
\text { ons }\end{array}$ & $\begin{array}{l}\text { Lacerat } \\
\text { ions }\end{array}$ & $\begin{array}{l}\text { Avuls } \\
\text { ion } \\
\text { Injuri } \\
\text { es }\end{array}$ & $\begin{array}{l}\text { Ureth } \\
\text { ral } \\
\text { Injuri } \\
\text { es }\end{array}$ & $\begin{array}{l}\text { Conserv } \\
\text { ative }\end{array}$ & $\begin{array}{l}\text { Opera } \\
\text { tive }\end{array}$ & $\begin{array}{l}\text { Abdo } \\
\text { men }\end{array}$ & $\begin{array}{l}\text { Oth } \\
\text { ers }\end{array}$ & $\begin{array}{l}\text { Che } \\
\text { st }\end{array}$ & $\begin{array}{l}\text { Abdo } \\
\text { men }\end{array}$ & $\begin{array}{l}\text { Oth } \\
\text { ers }\end{array}$ \\
\hline $\begin{array}{l}201 \\
5\end{array}$ & 629 & 390 & 239 & 71 & $\begin{array}{l}35 \\
6\end{array}$ & $\begin{array}{l}20 \\
2\end{array}$ & 416 & 121 & 43 & 3 & 03 & 01 & 07 & 15 & 04 & 09 & 06 \\
\hline $\begin{array}{l}201 \\
6\end{array}$ & 471 & 288 & 183 & 38 & $\begin{array}{l}26 \\
8\end{array}$ & $\begin{array}{l}16 \\
5\end{array}$ & 307 & 90 & 33 & 4 & 03 & 02 & 02 & 19 & 02 & 06 & 03 \\
\hline
\end{tabular}

\section{Discussion}

Emergency surgery is an acute specialty where decisions should be taken as quickly as possible. Information needs to be gathered quickly and appropriate management started. Most of the surgeries were performed in emergency situations where the value of the exhaustive investigations has to be balanced against any deterioration which may occur in patient general condition due to inevitable delay. As this study deals with the incidence of emergency surgeries, the cases are divided into trauma and non-trauma, out of which trauma cases were majority. A total of 2372 patients, 60.95 $\%$ are males and $39.05 \%$ are females with the age group of 5 - 92 years underwent emergency surgery. The surgeries included $61.07 \%$ (1449) of Trauma \& $38.93 \%$ (923) of Nontrauma cases. Among trauma, those with minor injuries that needed conservative and minor surgery are higher in number than those with major injuries. Among non-trauma cases, Appencitis cases $51.24 \%$ (472) were higher in number when compared to other non-trauma cases. Majority of the appendicitis cases were males aged 12-30 years. Appendicular perforations were observed in 136(28.8\%) 
cases. Intestinal obstruction cases accounted for $34.90 \%$ (322) and hollow viscus perforations accounted for $12.03 \%$ (114) of non-trauma cases. Majority of the intestinal obstruction cases were males aged more than 30 years. Among Intestinal obstruction cases, adhesions were observed in $170(52.2 \%)$ cases, obstructed hernias were observed in $84(26.0 \%)$ cases, Sigmoid volvulus was observed in $29(9.0 \%)$ cases and malignant change was observed in $23(7.1 \%)$ cases. Among hollow viscus perforations, Du perforation cases were maximum $(61.4 \%)$. Most of the surgeries were performed under spinal anaesthesia. A few cases were performed under General anaesthesia. Among trauma cases, $85.16 \%$ (1234) of them were minor injuries that required conservative management or minor surgeries \& $14.84 \%$ (215) of them were managed with major surgery. Majority of the trauma cases were males aged 12-30 years. Abrasions were the majority of traumatic surgical emergencies operated upon(65.5\%). This research was first of a kind in Telangana which aimed at identifying the spectrum of surgical emergencies and their outcome.

\section{Conclusion}

Among non-trauma cases, most of the cases were of intestinal obstruction and most of the surgeries were performed under spinal anaesthesia. Among trauma cases, most of them were minor injuries that required conservative management or minor surgeries and few of them were managed with major surgery.

\section{References}

1. Halstead WS. The training of the surgeon. Bull John Hopkins Hosp. 1904;15:267-75.

2. Farmer PE, Kim JY. Surgery and global health a view from beyond the OR. World J Surg 2008; 32: 533-536.

3. Debas HT, Gosselin R, McCord C, Thind A. Disease Control Priorities in Developing Countries. World Bank: Washington, DC, 2006.

4. Weiser TG, Regenbogen SE, Thompson KD, Haynes AB, Lipsitz SR, Berry WR et al. An estimation of the global volume of surgery: a modelling strategy based on available data. Lancet 2008; 372: 139-144.

5. Havens JM, Peetz AB, Do WS, et al. The excess morbidity and mortality of emergency general surgery. J Trauma Acute Care Surg. 2015;78(2):306-311.

6. Lozano R, Naghavi M, Foreman K, Lim S, Shibuya K, Aboyans V et al. Global and regional mortality from 235 causes of death for 20 age groups in 1990 and 2010: a systematic analysis for the Global Burden of Disease Study 2010. Lancet 2012; 380: 2095-2128.

7. Murray CJ, Vos T, Lozano R, Naghavi M, Flaxman AD, Michaud C et al. Disability- adjusted life years (DALYs) for 291 diseases and injuries in 21 regions, 1990-2010: a systematic analysis for the Global Burden of Disease Study 2010. Lancet 2012; 380: 2197-2223.

8. Institute for Health Metrics and Evaluation (IHME). Data Visualization.

Copyright: (C) the author(s), 2019. It is an open-access article distributed under the terms of the Creative Commons Attribution License (CC BY 4.0), which permits authors to retain ownership of the copyright for their content, and allow anyone to download, reuse, reprint, modify, distribute and/or copy the content as long as the original authors and source are cited.

How to cite this article: Yugandhar GR, Surender L, Chalam PV, Prakash B, Shekhar R, Kovida. Incidence of Surgical Emergencies - A Hospital Based Study in Ranga Reddy District of Telangana. Acad. J Surg. 2019;2(1):34-36.

DOI: dx.doi.org/10.21276/ajs.2019.2.1.10

Source of Support: Nil, Conflict of Interest: None declared. 